\title{
The First Accounting Course: An Outcomes Assessment Approach Project
}

\author{
David F. Bean, (Email: dbean@iona.edu), Iona College
}

Richard A. Bernardi, (Email: rbernardi@rwu.edu), Roger Williams University

\begin{abstract}
This paper discusses a class project that can be used in an introductory accounting class as an outcomes assessment tool. The project is done in groups of four to five students. Each student analyzes one company's ratios for a two year period and compares their firm's ratios with their firm's industry's ratios. When this is complete, the group then uses the individual firm data to make an investment decision. The investment decision must be based on the data from the individual firm ratios. Once the group has decided which firm to invest in, they then have to complete a pro-forma income statement for the firm assuming a \$2 billion expansion. Overall, the project is done in steps that help the students build their final project throughout the semester. The project is submitted at the beginning of the $13^{\text {th }}$ week of classes so that the instructor can grade it and hand it back to the students at the beginning of the $14^{\text {th }}$ week of classes. The groups present their projects during the last two class periods of the semester.
\end{abstract}

\section{Introduction}

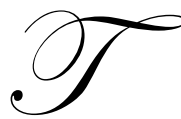

he impetus for much of the focus on outcome assessment in institutions of higher education arises from employer complaints about the quality of recent graduates. The arena is increasingly subject to congestion and instability due to various levels of government expressing concerns about higher education's increasing consumption of significant taxpayer and parental resources (Levinson 2001). As a result, the marketplace is exerting a considerable influence on both academic programs and outcome assessment (Sims 1992).

The U.S. Department of Education (1988) requires accrediting bodies to include assessment in their standards and this necessitates that most institutions of higher education become actively engaged in the practice of outcomes assessment. Not surprisingly, there is now an increased emphasis on learning outcomes relative to other accreditation standards and an assurance program that requires institutions to have plans for assessing outcomes that will help accomplish institutional goals (Morse and Santiago 2000). In its most general sense, outcome assessment is merely the evaluation of student performance with respect to specific educational objectives (Ewell 1988; Apostolou 1999) ${ }^{1}$

Many institutions view outcomes assessment in a positive light. They credit outcome assessment programs with increasing attention to teaching and curriculum, and this is often accompanied by fresh evaluations of the curriculum and improvements in the program (Kren et al. 1993; Kimmell et al. 1998). The implementation of an outcomes assessment program is not without attendant difficulties and concerns. Obviously a single measurement is incapable of capturing all educational outcomes and a combination of assessment measurements is necessary (Hill et al. 1998). Accounting program directors and others can find solace and detailed guidance for the assessment process in Stivers et al. (2000). Regardless of ones personal conviction, outcome assessment is a reality that is both omnipresent and here to stay. 


\section{Learning}

The evolution and improvement of accounting programs is an essential and ongoing process at institutions (Herring and Izard 1992). Learning, however, is a collaborative venture. The process of learning is typically both directive and participative, as student characteristics and instructional activities are co-contributors to learning outcomes. The influence of student affective characteristics, e.g. academic self-concept and achievement expectancies, as predictors of achievement and overall grade performance cannot be overlooked, as they are critical components in the learning process (Gordon 1989; Wilhite 1990; House 1995). Not surprisingly, the literature on outcomes assessment suggests that success is dependent upon the activities of the multiple stakeholders administrators, faculty, parents, taxpayers and students.

\section{Accreditation and Outcome Assessment Measures}

Agencies accrediting academic institutions and their programs require verification of the quality of academic outputs. The consensus view is that the process of assessment is inseparable from that of accreditation on the part of both regional and discipline based accrediting agencies (Kimmel et al. 1998). The accounting disciplines academic arm, the American Accounting Association (AAA 1993, 1), defines outcomes assessment as:

[A]n assessment of learning outcomes, and provides information on the question: What has been the learning achievement produced by the intervention in meeting its particular goals?"

Outcome assessment may be clothed in a variety of measures that are both objective and/or subjective. Standardized testing continues to be very popular as it is relatively inexpensive, often accompanied by instantaneous "brand name" recognition in terms of objectivity and reputation, relatively easy to administer, and often permits comparisons to what are designated as peer institutions. However, the anti-testing movement (Sacks 1997) has generated support for those colleagues who advocate performance assessment. They argue that evaluation should be based on what one can do rather than on "standardized tests". Within this venue, students perform a task rather than selecting from a predetermined list (e.g., using a multiple choice format). Advocates of performance assessment maintain that it leads to improved instruction in a more active context because students are required to demonstrate learning. Others propose that small-scale assessment techniques (CATS) should be used during classes. CATS are techniques such as questionnaires and short un-graded exercises, typically anonymous, whose purpose is to find out what students actually know. Angelo and Cross (1993) suggest that the feedback associated with CATS can help students become more effective, self assessing, and self directing learners.

The general objective of the introductory accounting course, when a users' perspective is the preferred instructional choice, is a broad introduction to accounting. The typical users' perspective course focuses on how accounting information can be used to make better decisions and how to use the accounting information found in financial statements and annual reports. The outcomes assessment project described in the remainder of the paper is adaptable to both a performance based and CATS based approach. The requirements of the project are such that it is easily adaptable to institutions with considerable technology support (e.g., Compustat) and those with minimal resources (e.g., internet).

\section{Final Project}

An understanding of the role of accounting information in business and society is essential to a successful career for the majority of business majors (Choi, 1993; AECC, 1992; and Dansereau, 1987). At the present time, one of the primary pedagogical issues confronting accounting academicians is whether or not knowing how to prepare financial statements is a requisite skill to understanding how to use accounting information (Pincus, 1997a, 1997b; Vangermeersch, 1997a, 1997b; AECC, 1992; Kinney, 1990; Arthur Andersen et al., 1989; Subotnik, 1987). While some argue that a preparer oriented introductory course is essential (e.g. Vangermeersch, 1997a, 1997b) others argue for emphasis on other important skills (Pincus 1997a, 1997b). The project presented in this paper was developed for either version of the introductory accounting course. By design, the project is flexible and can accommodate the particular goals and objectives of the individual instructor. 
The project is assigned to students in the first introductory accounting course, which normally includes freshmen and sophomores. Course objectives include understanding the discipline of accounting, the role of computer and other technology in accounting, the strengths and limitations of accounting information, and how to apply accounting information in the business decision making process. The project can be adapted to enhance skills emphasized by the AECC (1992), Bedford Committee (AAA 1986) and others. These skills include written communication, oral presentation, and group and team building.

\section{Group Composition}

Our approach has been to assign individuals to groups based on a variety of factors. The first grouping was done on availability for group work during evenings; because of evening classes, this is usually a MondayWednesday or Tuesday-Thursday schedule. Groups of four or five were then arranged; ideally, each group should contain a variety of majors so that students do not see business as a series of stovepipes. Our experiences suggest that four or five is an ideal group size because of mix and schedule constraints as well as potential attrition during the course. While allowing students to choose their groups is an option, it does not enhance the business requirement of working with persons from other departments on projects.

TABLE 1

SEMESTER SCHEDULE WITH GROUP MILESTONES

\begin{tabular}{|c|c|c|c|c|}
\hline $\begin{array}{l}\text { Week } 1-\text { Ch01 } \\
\text { Basics of Accounting }\end{array}$ & $\begin{array}{l}\text { Week } 2-\mathrm{Ch} 02 \\
\text { Debits and Credits } \\
\text { Financial Statement }\end{array}$ & $\begin{array}{l}\text { Week } 3 \text { - Ch03 } \\
\text { Measuring Income } \\
\text { Adjusting Entries }\end{array}$ & $\begin{array}{l}\text { Week } 4-\text { Ch05 } \\
\text { Financial Analysis } \\
\text { Assign Companies }\end{array}$ & $\begin{array}{l}\text { Week } 5-\text { Ch06 } \\
\text { Merchandizing } \\
\text { Test } 1\end{array}$ \\
\hline $\begin{array}{l}\text { Week } 6 \text { - Test } 1 \\
\text { Ch28 Financial Eval } \\
\text { Assign Groups }\end{array}$ & $\begin{array}{l}\text { Week } 7 \text { - Ch12 } \\
\text { Contrib Capital } \\
\text { HI: Firm ratios }\end{array}$ & $\begin{array}{l}\text { Week } 8-\text { Ch13 } \\
\text { S/E State \& IS } \\
\text { HI: Industry ratios }\end{array}$ & $\begin{array}{l}\text { Week } 9-\text { Ch11 } \\
\text { L/T Liabilities } \\
\text { \#1 Group Meeting }\end{array}$ & $\begin{array}{l}\text { Week } 10 \text { - Test } 2 \\
\text { Ch08 -- Inventory } \\
\text { \#2 Group Meeting }\end{array}$ \\
\hline $\begin{array}{l}\text { Week } 11-\text { Cont } 08 \\
\text { Inventories } \\
\text { \#3 Group Meeting }\end{array}$ & $\begin{array}{l}\text { Week } 12-\text { Ch10 } \\
\text { Long-term Assets } \\
\text { Complete Written } \\
\text { Part of Project }\end{array}$ & $\begin{array}{l}\text { Week } 13-\text { Ch14 } \\
\text { Cash Flow } \\
\text { Hand in Projects } \\
\text { Build Power Point }\end{array}$ & $\begin{array}{l}\text { Week } 14 \\
\text { Continue CF } \\
\text { Build Power Point } \\
\text { Return Projects }\end{array}$ & $\begin{array}{l}\text { Week } 15 \\
\text { Group in Class } \\
\text { Presentations }\end{array}$ \\
\hline
\end{tabular}

Table 1 shows the semester schedule for the group project and its milestones. The authors use Financial \& Managerial Accounting (Needles et al., 2002); consequently, the chapter numbering refers to this text. As is evident from Table 1, the project has components in every week following the first exam. The group meetings are scheduled to provide the students with guidance. The subject for discussion in the first meeting is the individual student's write up of the differences between their firm and their industry. While it may seem harsh, the policy is that if the students come unprepared, the instructor will not reschedule the meeting - it is their obligation to catch up before the next meeting. The second meeting centers on choosing one company - the $\$ 500,000$ investment decision. Finally, the last meeting concerns the $\$ 2.0$ Billion plant expansion and how to fund it. Two of the class meeting days in the last week are for group presentations.

\section{Company Assignment}

We believe that, for a first project, it is absolutely essential that each company has had a profit in the last three years. Losses are difficult to assess and this is especially true for a first-time analysis. Each student receives their company immediately after the first exam. The scheduling of the chapters in the semester varies from the typical book sequence so that students complete the major chapter on ratios immediately following the first exam. Again, students could choose their own companies; however, they will usually select one where a family member is employed (i.e., they are already familiar with it) or one in which they are spellbound consumers. 
The authors screen the companies using reportgallery.com as the source for the initial selection of companies. Again, three years of profitable operations are advisable for this first project. We also look at companies that have inventories so that we can show the students the difference between manufacturing firms and merchandising firms. We have the students print out their firm's financial statements so that as we discuss the chapters on stockholders' equity and long-term debt we can refer them to the financial statements they are using to show how subjects relate to real life.

Students are initially assigned the task of visiting the institution's library and obtaining a copy of the Value Line report for the assigned companies. They are also required to go online and download the financial portion of the annual reports for their company. The authors also require the students to go online to a database such as Mergent and obtain their company's SIC number. During the week that the ratio chapter is discussed in class, we schedule a visit to the library so that each student is able to locate where the industry averages such as Dunn and Bradstreet's is located. This visit normally takes less than 20 minutes to run each group through what they are looking for and how to use the data.

Students are required to visit each company's Web Site on the Internet. Thus the project must incorporate tasks that accommodate the interests and technical levels of both beginners and experts. The technical aspects of the task involve the basics of finding the company's Website and downloading information. Most experienced students are not familiar with the content of corporate Web Sites, and this is generally a novel experience for them.

\section{Financial Analyses}

Most introductory accounting texts have a chapter dedicated to financial analysis. In an intellectual sense, the calculation of ratios, dollar changes, percents, and percent changes are simplistic, tedious, and repetitive processes. Because students may or may not be familiar with spreadsheet applications at this point, students are given the option of doing the calculations manually or using a spreadsheet program. The students are encouraged to seek assistance from group members and computer personnel for the requisite spreadsheet applications. The authors also use this as an opportunity to emphasize that spreadsheet skills are both practical and important.

Each group must choose from among their group's companies to make a $\$ 500,000$ investment decision. The students must justify their decision using the ratios they computed for their group's firms. A requirement, of equal importance, is to ensure that the student justifies their decision choice by referencing the information that has been acquired during the project. The justification process requires students to be knowledgeable about interpreting financial analyses (a primary course objective) and requires a well thought out logical argument to support their decision choice (written communication skill). At this point, the authors emphasize that different people with identical information often make different decision choices. This serves as an introduction to behavioral aspects of decision making (e.g. risk attitude and differential weightings of information). This is a particularly important task for accounting majors as it forces them out of a preparer mode and into an interpretive function (Harrison, 1993). It also forces them to confront the information gaps between the needs and goals of users and the resources of the reporting system (Baker, 1994).

After each group has selected the company in which to invest their $\$ 500,000$, they must now complete the computations necessary to select a way of financing a $\$ 2.0$ billion expansion of their manufacturing facilities. This expansion will allow them to increase sales by 50 percent and reduce the cost of goods sold per unit by 25 percent. In this part of the project, the students are required to compute their ratios for their firm for three financing options: an all debt option, an all equity option, and a 50/50 mix of debt and equity. The students must recommend to management the best way to finance the $\$ 2$ billion expansion based on the firm's new ratios for each option based on the industry averages.

In the third group meeting, we point out that the pro forma income statement does not change until after operating income for the method used to finance the expansion. We send each student a spread sheet that will compute net income for their firm if they input the correct data for the current year as shown in Table 2 (Panel A). Each group must now complete a pro forma income statement for the following year that increases sales by 50 
percent and reduces the individual unit cost of good sold by 25 percent. Also provided in Table 2 (Panel B) is a short example with the solutions for the performance and solvency ratios, which we provide each group as a handout. We also provide the students with a short outline (Appendix B) of how the group's written project should be formatted, which answers most of the questions in the final stages of the project.

The choice of which method to finance the expansion (i.e., a nice lead in to financial management) requires a well thought out logical argument to support their decision choice (written communication skill). In this part of the analysis, they must recompute the ratios for each option shown in Table 2 (Panel B) and then after comparing each option to their industry's ratios make a decision which way to finance the $\$ 2.0$ billion plant expansion. The guidance we provide is that if the firm has a higher debt-equity ratio than their industry, the group should try to "drive" the firm's debt-equity ratio back towards the industry's ratio using a larger portion of equity financing.

\section{Employment Decision}

Employment upon graduation is a major concern to both students and faculty, and the Web Site visit requires students to obtain information about employment opportunities at each company. After completing the $\$ 2.0$ billion plant expansion, the students are required to go out on the web and find jobs in each of their firms. In this part of the project, they must select a firm to work for and justify their decision with web-based data and with the financial data they computed in the first part of the project. An integral part of this portion of the project for each group member is to submit their resume. The authors believe that a resume should be prepared early in the college experience; this project is an ideal vehicle to introduce the importance of building a resume. The student has just completed a decision choice between two different companies that are essentially competing for the student's monetary resources, career commitment, and time. Their decision was based on the information they gathered on all of their companies. Similarly, companies make decisions about who to hire based on the information they have about their applicants. Much of this information appears on the initial resume sent in by the prospective employee.

The process of writing a resume serves as a "reality check" for many students; it forces them to ponder what they have to offer to an employer. The project provides an opportunity to emphasize: (1) that there are real costs associated with poor performance - grades; (2) the importance of becoming involved in extracurricular activities - interpersonal skills; and (3) the importance of joining organizations and assuming officer positions professional commitment, communication, and leadership skills. Writing one's first resume is a difficult task and it is important to emphasize that a resume is not created in a single attempt; a resume evolves over a series of rewrites. Additionally, this is an excellent opportunity to introduce students to the various "career" and "placement" services at the institution.

The authors note that the same company would not necessarily be selected for each decision choice or for all students. The course emphasizes accounting as a tool for decision making. The student in an information search that requires choices concerning resource allocations is investing considerable time and effort. For many students, this is a dilemma, because they are unconfident about the decision process and want to avoid it. They may even attempt to maneuver the instructor into making the choice for them. It is crucial that the decision choice be the students' selection. Because students will make many decisions throughout their professional and personal lives, it is important to personally experience the act of making choices. Due to cost-benefit tradeoffs, there is a limit to the resources that can be spent on the search process. As a result, choices are often made with incomplete information; the project forces students to confront this reality.

\section{Grading the Project}

Appendices $\mathrm{C}$ and $\mathrm{D}$ are provided for the instructor's use in grading the project. The authors grade the paper for both content and grammar. In fact, we also provide the students with a copy of Appendix $C$ so that they are fully aware of how we are going to grade their paper and what weights each section of the paper is worth. Appendix D is used for the in-class presentations of the students' projects. We believe that asking the students to evaluate their peers is a very good lesson in active listening. It allows the students to see the strong points and errors that other students make in their presentations. We factor the students' evaluations as 40 percent of the in-class presentation score. 
Panel A: Pro-forma Income Statements by Financing Option for \$2.0 Billion Plant Expansion

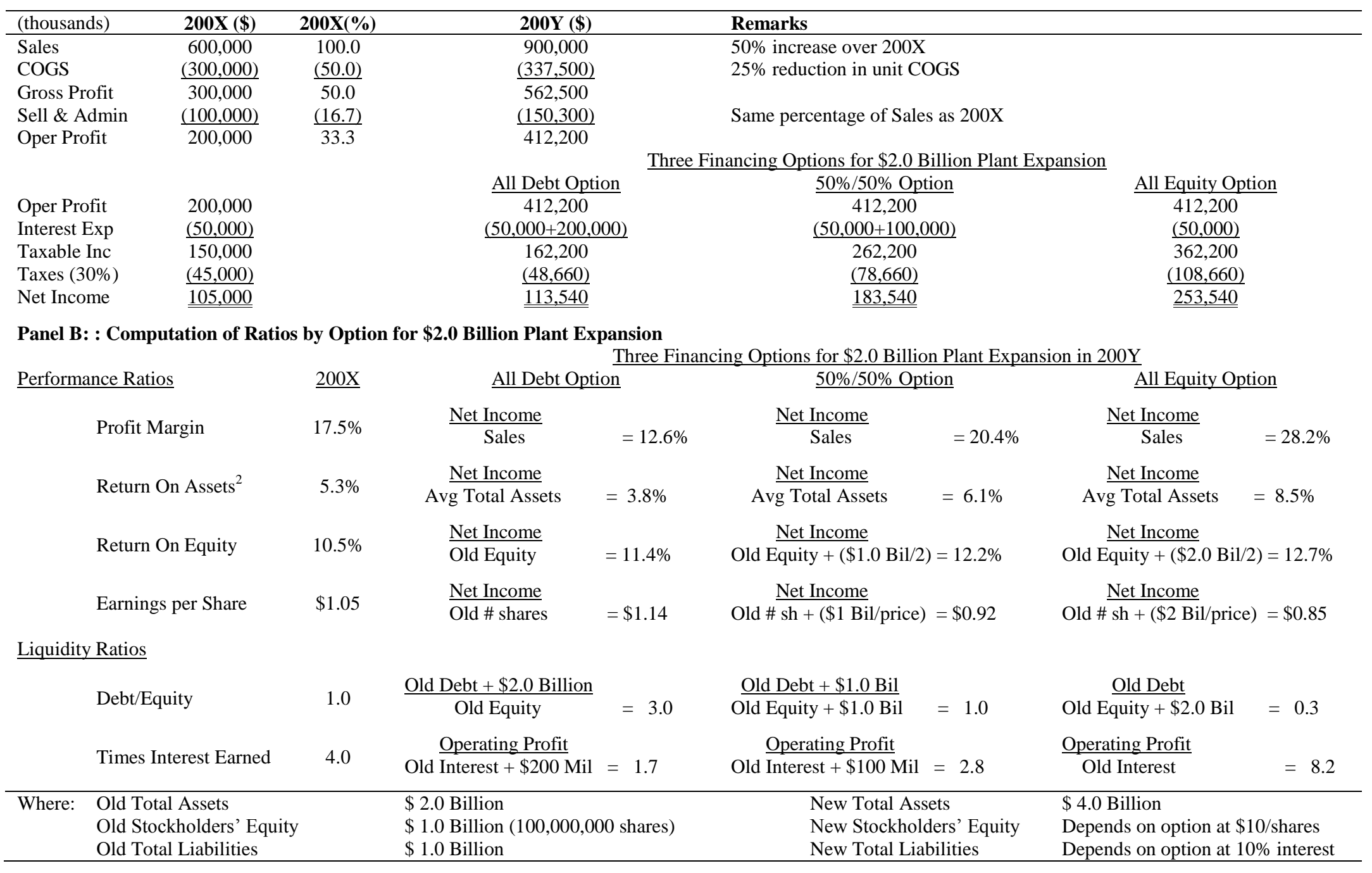


At the end of the group presentations, we have the students do peer evaluations of their group. We tell the students about this part of the grading at the time we form the groups. Our policy is that while a group may receive a grade of 90 percent, this does not mean that every member of the group deserves a 90 . We ask them to give us their estimation of how the points should be divided among their group, and we require that they justify in writing when they increase or decrease any member's individual grade. This procedure adjusts for the possibility of a person free riding in the project.

\section{Technology Issues}

Financial analyses comprises significantly more time periods than the two years that normally appears on a company's financial statements; students are informed of this reality. The authors use this, as a departure point, to elaborate upon the availability of electronic financial data banks (e.g., Compustat) and the importance of spreadsheet skills in lengthy analyses. Thus, the project introduces and reinforces the practical application of computer skills addressed in other courses, as well as exposing students to new databases.

Our group policy with respect to computer skills is that each individual member of the group must be fully literate about the computer applications utilized in the project. This is enforced by having the instructor pose questions to each individual in the group about the computer applications they employed. The two major benefits from this are: (1) a computer guru does not take on all computer responsibilities and (2) it aids in group coherence, because individual members are responsible for ensuring that all group members are competent in this area.

\section{Other Objectives}

While the project grading process does not include a thorough and detailed formal critique of writing, the authors use the written portion of the project as a vehicle to identify students that have marginal writing skills. The authors put a brief and encouraging note on the student's project, if they have substandard written communication skills. Because writing is essential for success in the workplace, follow-up effort to ensure that students address this weakness is at the discretion of the instructor; this ranges from a brief memo to a formal conference.

The authors also use the project as a vehicle for students to make oral presentations; students are required to present and justify their choices to the remainder of the class. Oral presentations are done as a group; each individual in the group is required to actively participate in the presentation. For many students, this is their first oral presentation experience and the authors' approach is one of constructive encouragement. Emphasizing oral presentations and their necessity in the workplace removes some student fears and many of our students subsequently enroll in communication courses to enhance these skills.

The authors are very satisfied with the project outcomes; however, it does involve a considerable investment of time on the part of the instructors. Furthermore the project requires continuous updating because of resource and technology changes within the institution. For some institutions, this can be unwieldy, especially if the necessary project resources are under the control of more than one department. Numerous variations on the project are possible; this is dependent upon the objectives, perspectives, and pedagogical preferences of the instructor. One might consider an intensive review of a single industry, comparisons of similar industries, wholesalers vs. retailers, etc. The Appendix is an individual student and group version of the project. It can be modified to incorporate group activities as well as other institutional and instructor preferences. The primary objective of the authors has been to provide a user-friendly introduction to the technological resources available at the institution. In our opinion, the project meets this objective and feedback from our students indicates that it is a valuable experience.

\section{Notes}

The authors are involved in several research projects and alternate lead author responsibilities. Both authors contribute equally to all of their published work.

1. Readers desiring a more complete discussion of the history of assessment should consider consulting Rebele et al. (1998), Kimmel et al. (1998) and Apostolou (1999). 
2. For Return on Assets (Return on Equity), dividing the amount of the expansion (funded by equity) by two provides the amount needed to be added to the denominator.

\section{References}

1. Accounting Education Change Commission (AECC). (1992). "The First Course in Accounting, Position Statement No. Two". Issues in Accounting Education, 7 (2), 249-252.

2. American Accounting Association (AAA) (1993). Report of the 1992-93 Outcomes Assessment Committee. Sarasota, FL.

3. American Accounting Association (AAA), Committee on the Future Structure, Content, and Scope of Accounting Education (The Bedford Committee). (1986). "Future Accounting Education: Preparing for the Expanding Profession". Issues in Accounting Education, 1 (Spring), 168-195.

4. Angelo, T. A. and K. P. Cross. (1993). Classroom Assessment Techniques: A Handbook for College Teachers. Second edition. San Francisco, CA. Jossey-Bass.

5. Apostolou, B. A. (1999). "Outcomes Assessment”. Issues in Accounting Education 14 (1): 177-197.

6. Arthur Andersen \& Co., Arthur Young, Coopers \& Lybrand, Deloitte Haskins \& Sells, Ernst \& Whinney, Peat Marwick Main \& Co., Price Waterhouse, \& Touche Ross. (1989). Perspectives on Education: Capabilities for Success in the Accounting Profession. New York.

7. Baker, W. M. (1994). "Shedding the Bean Counter Image". Management Accounting, October 29-31.

8. Choi, F. S. (1993). "Accounting Education for the $21^{\text {st }}$ Century: Meeting the Challenges". Issues in Accounting Education, 8 (Fall), 423-430.

9. $\quad$ Dansereau, D. F. (1987). “Technical Learning Strategies”. Education (February), 280-284.

10. Ewell, P. T. (1988). "Outcomes, Assessment, and Academic Improvement: In Search of Usable Knowledge". In Higher Education: Handbook of Theory and Research, edited by J. C. Smart. Agathon Press, New York, NY.

11. Gordon, R. A. (1989). "Intention and Expectation Measures as Predictors of Academic Performance". Journal of Applied Social Psychology 19: 405-415.

12. Harrison, S. R. (1993). "Not Just Bean Counters Anymore". Management Accounting. March 29-32.

13. Herring, H. C. III and C. D. Izard. (1992). "Outcome Assessment of Accounting Majors". Issues in Accounting Education 1(7): 1-17.

14. Hill, N. T., S. E. Perry, and D. M. Stein. (1998). "Using Accounting Student Surveys in an Outcomes Assessment Program". Issues in Accounting Education 13 (1): 65- 78.

15. House, J. D. (1995). "The Predictive Relationship Between Academic Self-Concept, Achievement Expectancies, and Grade Performance in College Calculus". Journal of Social Psychology 135: 111-112.

16. Kimmell, S. L., R. P. Marquette and D. H. Olsen. (1998). "Outcomes Assessment Programs: Historical Perspectives and State of the Art". Issues in Accounting Education 13 (4): 851-868.

17. Kinney, W. R. (1990). "Some Reflections on a Professional Education: It Should Have Been More Positive". Issues in Accounting Education, 6 (2), 293-301.

18. Kren, L., K. W. Tatum and L. C. Philips. (1993). "Separate Accreditation of Accounting Programs: An Empirical Investigation". Issues in Accounting Education, Fall: 260-272.

19. Levinson, A. (2001). “Colleges Begin to Ask if Students Get Their Money's Worth”. The Los Angeles Times, May 20: A15.

20. Morse, J. A. and G. Santiago, Jr. (2000). "Accreditation and Faculty Working Together". Academe, Jan./Feb. 86 (1): 30-36.

21. Needles, B. E., M. Powers, and S. V. Crosson. (2002). Financial and Managerial Accounting. Boston: Houghton Mifflin.

22. Pincus, K. V. (1997a). "Is Teaching Debits and Credits Essential in Elementary Accounting". Issues in Accounting Education, 12 (2) 575-579.

23. Pincus, K. V. (1997b). Reply. Issues in Accounting Education. 12 (2), 585.

24. Rebele, J. E., B. A. Apostolou, F. A. Buckless, J. M. Hassell, L. R. Paquette, and D. E. Stout. (1998). Accounting Education Literature Review (1991-1997), part II: "Students, Educational Technology, Assessment, and Faculty Issues". Journal of Accounting Education (Spring): 179-245. 
25. Sacks, P. (1997). "Standardized Testing: Meritocracy's Crooked Yardstick". Change Mar./Apr.: 25-31.

26. Sims, S. J. (1992). Student Outcomes Assessment: A Historical Review and Guide to Program Development. Greenwood Press, Westport, CT.

27. Stivers, B. P., J. E. Campbell, and H. M. Hermanson. (2000). “An Assessment Program for Accounting: Design, Implementation and Reflection". Issues in Accounting Education 15(4): 553-581.

28. Subotnik, D. (1987). "What Accounting Can Learn From Legal Education". Issues in Accounting Education, 2 (2), 313-324.

29. U.S. Department of Education. (1988). "Secretary's Procedures and Criteria for Recognition of Accrediting Agencies". Federal Register 53 (127). U.S. Government Printing Office, Washington, D. C.

30. Vangermeersch, R. G. (1997a). "Dropping Debits and Credits in Elementary Accounting: A Huge Disservice to Students". Issues in Accounting Education, 12 (2), 581-583.

31. Vangermeersch, R. G. (1997b). Rebuttal. Issues in Accounting Education, 12 (2), 587.

32. Wilhite, S. C. (1990). "Self-Efficacy, Locus of Control, Self-Assessment of Memory Ability, and Study Activities as Predictors of College Course Achievement". Journal of Educational Psychology, 82: 696-700.

\section{Appendix A \\ Accounting 101 Project Handout}

Individual Effort

1. Compute all of the ratios for your firm for 2001 and 2002. The computations by year will be your homework for the large ratios chapter after the first exam. Note: this homework is worth two percent of your final grade in the course. This part of the Project is an individual grade.

2. Obtain your company's SIC code from the Library's Mergent Online database. Bring this to class the day after the first exam. We will be going to the Library for a short time to look up your firm's industry balance sheet and income statement. Compute all of the ratios for your firm's industry for 2001 and 2002. The computations by year will be your second homework for the large ratios chapter after the first exam. Note: this homework is also worth two percent of your final grade in the course. This part of the Project is an individual grade.

Group Effort -- \$500,000 Investment Decision

1. The first part of this section of the project is for each group member to individually determine whether your company or the industry has the better ratio in each case. Each individual must do this before the group can really do anything.

2. Now you must write up your logic for determining whether your company or your industry had the best ratios. This is a section of the final written project.

3. Once you have your individual homework on ratios completed and your firm compared to your industry (3. above), your group should start meeting to determine which of your company's has the best performance. At this point, I will set up times so that each group can meet with me and I will explain how to go about evaluating the companies.

4. Now you must write up your logic for selecting your best company. Now you must write up your logic for determining which of your companies had the best ratios. This is a section of the final written project. This part of the Project is referred to as the $\$ 500,000$ Investment Decision.

Group Effort -- \$2.0 Billion Plant Expansion

1. In this section, your group will assume your best company is going to expand their production facilities by $\$ 2.0$ billion. This will increase sales by 50 percent above the 2002 level. It will also make your company's production more efficient and reduce the cost of goods sold per individual unit by 25 percent.

2. First, you need to develop a Pro Forma Income Statement for 2003 which reflects these changes. To determine how to finance the plant expansion, you must consider at least the following options: 1) all equity financing; 2) all debt financing; and 3) a 50/50 mix of debt and equity financing.

3. You have to compute your performance and solvency ratios for each of these options and compare the new ratios for each option with your industry ratios to determine which option to select. 
Individual Effort -- Using Financial Data in the Job-Search Process

1. Go online and find entry level jobs for business majors at each of your firms. Here each of you must evaluate the jobs available at each company and select a company to work for after graduation. This decision should take you about a page to justify and MUST include references to your firms' financial performance.

2. Finally, as you are in the job market, each group member must include a copy of their current resume as part of the project.

\section{Appendix B \\ Accounting 101 Project Submission Outline}

\begin{tabular}{cl} 
Part: & Area of Coverage \\
\hline 1 & Index \\
3 & Individual Firm versus Industry Comparisons \\
4 & \$200,000 Investment Decision \\
5 & Resumes and Job Decisions \\
App: & \\
A-E & Financial Statements for Each Firm \\
F+ & Other Documentation
\end{tabular}

$\underline{\text { Length (pages) }}$

1

12 to 15 (group size)

2 to 3

2 to 3

12 to 15 (group size)

25 to 30 (group size)

as required

\section{Appendix C \\ Condensed Accounting 101 Project Evaluation Sheet - Written (4 person group)}

Group: , and

1. Individual Company Write Ups (20 Points)

2. $\$ 500,000$ Investment Decision (20 Points)

3. \$2.0 Billion Expansion Decision (20 Points)

4. Individual Employment Decision (20 Points)

5. Presentation: Wording and Graphics (20 Points):

$\overline{\overline{\text { Total Points }}}$ 


\section{Presentation Evaluation Form Accounting 101 Presentations \\ Appendix D}

The introduction captured my attention

One topic followed another in a logical order

Good examples were presented to illustrate points

Speakers were enthusiastic

Speakers spoke clearly

Speakers spoke neither too quickly nor too slowly

There were few "Ahs"

Speakers maintained good eye contact with the audience

Strongly

Disagree

Gestures enhanced presentation

AV materials enhanced the presentation

The conclusion wrapped up the presentation well

Presentation provided evidence of work

I learned something from this presentation

I enjoyed this presentation

(a)

What did you especially like about the presentation?

What one aspect of the presentation might have been done differently and why? 
Notes 